\title{
Perbedaan Frekuensi Defekasi dan Konsistensi Tinja Bayi Sehat Usia 0-4 Bulan yang Mendapat Asi Eksklusif, Non Eksklusif, dan Susu Formula
}

\author{
Noverita Rochsitasari, ${ }^{*}$ Budi Santosa, ${ }^{*}$ Niken Puruhita** \\ * Bagian Ilmu Kesehatan anak Fakultas Kedokteran Universitas Diponegoro/RSUP Dr. Kariadi, Semarang \\ ** Bagian Ilmu Gizi Klinik Fakultas Kedokteran Universitas Diponegoro/RSUP dr.Kariadi, Semarang
}

Latar belakang. Pola defekasi masa bayi sangat bervariasi, sehingga diperlukan data pola defekasi normal pada bayi yang mendapat ASI atau susu formula.

Tujuan. Untuk mengetahui adanya perbedaan frekuensi defekasi dan konsistensi tinja bayi sehat umur 0-4 bulan yang mendapat ASI eksklusif, non eksklusif, dan susu formula.

Metode. Penelitian observasional longitudinal, prospektif, metode time series. Dilakukan di RSUP Dr.Kariadi, RS Kota Semarang, dan RS St Elizabeth Semarang. Subyek yang memenuhi kriteria inklusi diamati pada usia 0-4 bulan. Sampling dengan purposive random, dikelompokkan sesuai dengan jenis diet (ASI ekslusif, non ekslusif, dan susu formula). Frekuensi defekasi adalah jumlah berapa kali defekasi/hari selama tiga hari terakhir. Konsistensi tinja adalah tingkat kepadatan atau bentuk tinja sesuai American baby stool form, dicatat pada hari pertama, ketiga dan ketujuh, bulan pertama sampai keempat. Analisis statistik menggunakan Uji Chi square, Kruskal Wallis, dan Friedman.

Hasil. Subjek terdiri dari 73 bayi.Terdapat perbedaan bermakna rerata frekuensi defekasi pada ketiga kelompok ASI eksklusif, non- eksklusif, dan susu formula pada hari ketiga $(p=0,05)$, ketujuh $(p=0,00)$, bulan ketiga $(\mathrm{p}=0,01)$ dan keempat $(\mathrm{p}=0,01)$, namun tidak bermakna pada hari pertama $(\mathrm{p}=0,293)$, bulan pertama $(p=0,30)$, dan kedua $(p=0,19)$. Terdapat penurunan bermakna frekuensi defekasi bayi ASI eksklusif dari bulan pertama sampai keempat $(\mathrm{p}=0,00)$. Terdapat perbedaan bermakna konsistensi tinja hari pertama $(\mathrm{p}=0,028)$ ketiga $(\mathrm{p}=0,005)$, ketujuh $(\mathrm{p}=0,00)$ bulan pertama sampai keempat masing-masing $(\mathrm{p}=0,00)$, tidak terdapat hubungan bermakna frekuensi defekasi dengan konsistensi tinja pada hari pertama $(\mathrm{p}=0,405)$, bulan pertama ( $p=0,059)$,dan kedua ( $p=0,068)$. Terdapat hubungan bermakna frekuensi defekasi dengan konsistensi tinja pada hari ketiga $(\mathrm{p}=0,041)$, ketujuh $(\mathrm{p}=0,00)$, bulan ketiga $(\mathrm{p}=0,013)$, dan keempat $(\mathrm{p}=0,049)$.

Kesimpulan. Rerata frekuensi defekasi bayi kelompok ASI eksklusif pada bulan pertama lebih tinggi dibandingkan kelompok lain. Terdapat perbedaan frekuensi defekasi pada ketiga kelompok bayi sehat pada hari ketiga, ketujuh, bulan ketiga, dan keempat Terdapat perbedaan konsistensi tinja pada ketiga kelompok. Terdapat hubungan frekuensi defekasi dengan konsistensi tinja pada hari ketiga, ketujuh, bulan ketiga, dan keempat. Sari Pediatri 2011;13(3):191-9.

Kata kunci: frekuensi defekasi, konsistensi tinja, ASI, susu formula,bayi

\author{
Alamat korespondensi: \\ Dr. Noverita Rochsitasari. Bagian Ilmu Kesehatan Anak RS Dr Kariadi \\ Semarang. Jl. Dr. Sutomo no.18 Semarang. Email: nover.sita@yahoo.com
}

Sari Pediatri, Vol. 13, No. 3, Oktober 2011 


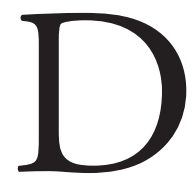
efekasi atau buang air besar (BAB) adalah suatu proses evakuasi tinja dari dalam rektum, yang terdiri dari bahan yang tidak digunakan lagi dan harus dikeluarkan dari dalam tubuh. ${ }^{1}$ Pola defekasi pada anak sangat bervariasi dan sangat bergantung pada fungsi organ, susunan saraf, pola makan, serta usia anak. Menilai pola defekasi pada anak berarti menilai frekuensi defekasi, konsistensi dan warna tinja. ${ }^{2,3}$ Tidak didapatkan perbedaan warna tinja $(\mathrm{p}=0,43)$ pada bayi yang mendapat susu formula dengan yang mendapat ASI. ${ }^{4}$ Belum ada bukti yang jelas untuk mengetahui jumlah normal frekuensi defekasi pada bayi baru lahir yang mendapatkan ASI atau susu formula. Frekuensi BAB sangat bervariasi. Bayi yang memiliki reflek gastrokolik yang kuat, sehingga dapat mengalami BAB tiap kali menyusu. Paling sedikit, bayi BAB tiga kali setelah usia 3-4 hari dan berlanjut sampai bulan pertama. Konsistensi tinja lembek dan berbau khas. ${ }^{5}$ Pengaruh ASI terhadap frekuensi defekasi terutama terjadi pada bayi yang mendapatkan ASI eksklusif sampai dengan umur 16 minggu. Setelah bayi mulai mendapatkan makanan pendamping maka tidak didapatkan lagi perbedaan frekuensi defekasi yang bermakna antara bayi yang mendapatkan ASI dengan bayi yang mendapatkan susu formula. ${ }^{6,7}$ Penelitian mengenai pola defekasi pada anak sebagian besar dilakukan pada anak di Amerika, Eropa, Australia, dan Thailand. ${ }^{7,8,9,10}$

Pengamatan terhadap frekuensi dan konsistensi tinja penting dilakukan oleh perawat rumah sakit dan orang tua bayi. Orang tua muda yang baru pertama kali mempunyai anak, banyak yang tidak mengetahui akan hal ini dan sering mengkhawatirkan tentang konsistensi tinja atau frekuensi defekasi bayi mereka. Banyak pertanyaan yang muncul mengenai bagaimana pola defekasi anak yang normal kepada dokter di tempat praktek. ${ }^{5}$ Tigapuluh persen ibu mempercayai bahwa bayi baru lahir yang BAB setiap kali setelah minum atau pada bayi yang mendapat ASI eksklusif BAB tiap lima hari, sekali merupakan suatu gejala penyakit yang serius dan memerlukan perhatian medis segera. ${ }^{11}$ Belum banyak data mengenai pola defekasi pada anak di Indonesia. Dilaporkan baru satu penelitian yang telah dilakukan pada tahun 2003 tentang frekuensi defekasi, konsistensi dan warna tinja pada bayi umur 0-4 bulan yang mendapatkan ASI eksklusif. ${ }^{12}$

Para dokter terutama dokter spesialis anak, seharusnya memahami pola defekasi normal pada bayi dan anak. Hal ini bermanfaat untuk memberi edukasi, menghindarkan dari rasa cemas orang tuanya dan menghindari tindakan atau pemberian obat-obatan yang tidak diperlukan sehubungan dengan keluhan pola defekasi pada bayi atau anak mereka, sehingga biaya pengobatan yang dikeluarkan lebih efisien dengan hasil pengobatan yang lebih efektif. ${ }^{6}$

Penelitian bertujuan untuk mengetahui perbedaan pola defekasi pada bayi sehat usia $0-4$ bulan yang mendapat ASI eksklusif, non eksklusif, dan susu formula terhadap frekuensi defekasi dan konsistensi tinja.

\section{Metode}

Penelitian observasional longitudinal prospektif, menggunakan metode time series. Subjek penelitian adalah bayi lahir aterm, sehat yang lahir di Kodya Semarang selama kurun waktu Juli - Desember 2010, di ruang rawat gabung RS Dr. Kariadi, RS Kota Semarang dan RS St Elisabeth. Kriteria inklusi adalah bayi lahir genap bulan dan sehat serta tidak didapatkan kelainan kongenital mayor. Orang tua memberikan persetujuan ikut dalam penelitian sampai dengan anak berusia 4 bulan. Subyek tidak diikutsertakan apabila memiliki gangguan neuroanatomi, kelainan kongenital pada saluran cerna, mengkonsumsi obat-obatan yang mempengaruhi saluran cerna, riwayat ibu menderita penyakit tiroid atau mengkonsumsi obat-obatan selain vitamin selama hamil dan menyusui (misal obat tiroid), serta menderita perdarahan saluran cerna. Subyek dikeluarkan dari penelitian, apabila dalam masa pengamatan mengalami perubahan pola diet lebih dari dua minggu berturut-turut dan tidak kembali ke diet semula dan apabila dalam masa pengamatan mengalami gangguan pola defekasi lebih dari tiga minggu dalam satu bulan yang sama.

Pengambilan subjek penelitian dilakukan dengan secara purporsive sampling, lalu dikelompokkan sesuai dengan jenis diet (ASI ekslusif, non ekslusif, dan susu formula). Frekuensi defekasi adalah jumlah berapa kali anak defekasi dalam sehari atau rerata selama tiga hari terakhir. Didapat dari pernyataan orang tua melalui kuesioner yang diisi oleh petugas. Konsistensi tinja adalah tingkat kepadatan atau bentuk tinja dominan sesuai dengan American Baby Stool form. ${ }^{14}$ Didapatkan surat persetujuan dari orang tua untuk ikut dalam penelitian. Konsistensi tinja dikelompokkan menjadi tiga kategori, yaitu keras, lembek berbentuk, dan lembek cair. 
Saat bayi baru lahir dan masih berada di rumah sakit, ditanyakan kepada ibu atau walinya data anak yaitu nama, alamat dan nomor telepon orang tua, umur, jenis kelamin, riwayat kelahiran, obat-obatan yang dikonsumsi ibu selama hamil dan pemberian ASI/susu formula frekuensi defekasi, konsistensi tinja, dan warna tinja. Saat bayi berusia 3, 7 hari, dan 1, 2, 3, 4 bulan, kembali dicatat frekuensi defekasi, dan konsistensi tinja, data didapatkan melalui kunjungan ke BKIA/Posyandu atau kunjungan rumah. Data pasien akan dicatat pada lembar data yang khusus disediakan untuk penelitian. Sebelum dilakukan penelitian, para ibu akan dilatih terlebih dahulu untuk menyamakan persepsi antara penelitian dan mengenai bentuk, konsistensi dan warna tinja bayi mereka menggunakan gambar yang telah disediakan oleh peneliti.

Perbedaan karakteristik antar kelompok diuji dengan Chisquare untuk data yang bersifat kategorikal. Untuk data yang berskala numerik seperti umur gestasi saat dilahirkan dinyatakan sebagai median dan persentil, diuji dengan Kruskal-Wallis karena distribusi yang tidak normal. Selanjutnya data dianalisis secara inferensial untuk menguji hipotesis. Nilai p dianggap bermakna apabila $\mathrm{p}<0,05$. Uji beda rerata frekuensi defekasi antar kelompok dilakukan pada bulan 1, 2, 3, dan 4 dengan uji Kruskal-Wallis. Uji komparatif konsistensi tinja antar kelompok dilakukan pada bulan 1, 2, 3, dan 4 menggunakan uji Chi square. Perbedaan frekuensi defekasi bulan ke 1, 2, 3, dan 4 untuk masing-masing kelompok diuji menggunakan GLM Repeated Measure. Perbedaan konsistensi tinja bulan 1, 2, 3, dan 4 untuk masing-masing kelompok diuji menggunakan uji Friedman. Hubungan antara frekuensi defekasi dengan konsistensi tinja, dinilai menggunakan uji Kruskal wallis.

Penelitian telah disetujui oleh Komite Etik Penelitian Kedokteran Fakultas Kedokteran Universitas Diponegoro/RS Dr. Kariadi Semarang, dan dimintakan inform consent dari orang tua. Keterbatasan penelitian adalah tidak melakukan pengukuran volume ASI tiap kali minum, jenis makanan ibu, kadar hormon, dan elektrolit bayi.

Tabel 1. Karakteristik subyek penelitian $(n=73)$

\begin{tabular}{|c|c|c|c|c|c|c|c|c|c|}
\hline \multirow[t]{2}{*}{ Karakteristik } & \multicolumn{3}{|c|}{$\begin{array}{c}\text { ASI } \\
\text { eksklusif }\end{array}$} & \multicolumn{3}{|c|}{$\begin{array}{c}\text { ASI } \\
\text { nonekslusif }\end{array}$} & \multicolumn{2}{|c|}{$\begin{array}{c}\text { Susu } \\
\text { formula }\end{array}$} & \multirow[t]{2}{*}{ Nilai p } \\
\hline & $n=26$ & & $(\%)$ & $\mathrm{n}=23$ & & $(\%)$ & $\mathrm{n}=24$ & $(\%)$ & \\
\hline \multicolumn{10}{|l|}{ Jenis kelamin } \\
\hline Laki-laki & 16 & & 61,5 & 11 & & 47,8 & 17 & 70,8 & $0,269^{*}$ \\
\hline Perempuan & 10 & & 38,5 & 12 & & 52,2 & 7 & 29,2 & \\
\hline \multicolumn{10}{|l|}{ Cara lahir } \\
\hline Spontan & 19 & & 73,1 & 13 & & 56,5 & 19 & 79,2 & $0,217^{*}$ \\
\hline Tindakan & 7 & & 26,9 & 10 & & 43,5 & 5 & 20,8 & \\
\hline \multicolumn{10}{|c|}{ Riwayat konstipasi keluarga } \\
\hline Ada & 4 & & 15,4 & 6 & & 26,1 & 1 & 4,2 & $0,10^{*}$ \\
\hline Tidak ada & 22 & & 84,6 & 17 & & 73,9 & 23 & 95,8 & \\
\hline Masa gestasi & 38,75 & 3025 & 40 & 38 & 39 & 39 & 39 & 39 & $0,538^{* *}$ \\
\hline
\end{tabular}

Tabel 2. Frekuensi defekasi bulan 0-4 masing-masing kelompok

\begin{tabular}{lccccccccc}
\hline \multirow{2}{*}{$\begin{array}{l}\text { Frekuensi } \\
\text { defekasi }\end{array}$} & \multicolumn{3}{c}{ ASI eksklusif } & \multicolumn{3}{c}{ ASI non eksklusif } & \multicolumn{3}{c}{ Susu formula } \\
\cline { 2 - 10 } median & $\min$ & $\max$ & median & $\min$ & $\max$ & median & $\min$ & $\max$ \\
\hline Hari I & 2 & 1 & 8 & 2 & 1 & 6 & 3 & 1 & 5 \\
Hari III & 4 & 1 & 12 & 3 & 1 & 8 & 2,50 & 1 & 5 \\
Hari VII & 6 & 1 & 12 & 3 & 1 & 8 & 3 & 1 & 4 \\
Bulan I & 3 & 0,14 & 8 & 2 & 1 & 5 & 2 & 0,33 & 4 \\
Bulan II & 1 & 0,14 & 5 & 1,3 & 0,3 & 4,3 & 2 & 0,33 & 3,33 \\
Bulan III & 0,33 & 0,10 & 5 & 1 & 0,33 & 4 & 2 & 0,33 & 3,6 \\
Bulan IV & 0,66 & 0,10 & 5 & 1 & 0,33 & 4 & 1,65 & 0,33 & 4 \\
\hline
\end{tabular}




\section{Hasil}

Pengamataan pasca anak lahir dilakukan pada 83 bayi, 9 bayi drop out karena tidak mengonsumsi diet semula lebih dari dua minggu dan satu bayi mengalami diare lebih dari tiga minggu. Jumlah akhir subyek yang dapat diamati selama 4 bulan adalah 73 bayi, terdiri dari 26 bayi yang mendapat ASI eksklusif, 23 bayi ASI non-eksklusif, dan 24 bayi mendapat susu formula.

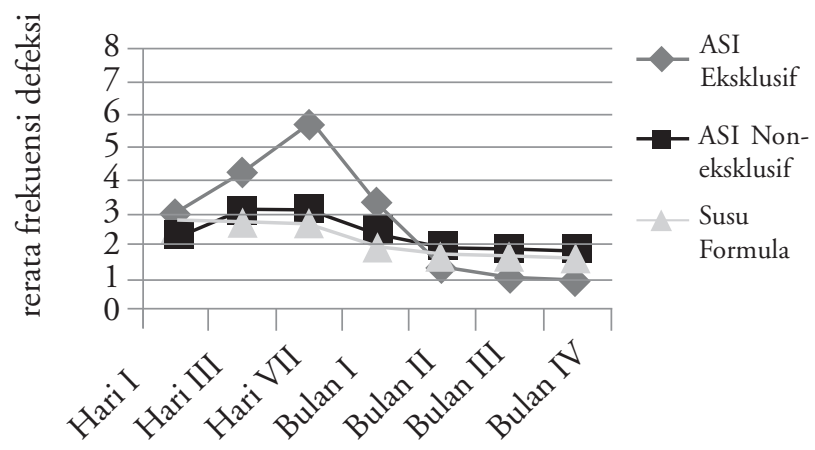

Gambar 1. Rerata frekuensi masing-masing kelompok dari hari pertama sampai bulan keempat.

\section{Karakteristik subjek penelitian}

Karakteristik subyek penelitian pada ketiga kelompok tertera pada Tabel 1 dan 2 . Tidak terdapat perbedaan karakteristik subyek penelitian pada ketiga kelompok.

\section{Frekuensi defekasi}

Selama pengamatan empat bulan didapatkan rerata frekuensi defekasi pada bulan pertama tampak lebih sering dibandingkan pada bulan berikutnya pada ketiga kelompok. Penurunan rerata ini lebih tampak kelompok ASI eksklusif (Gambar 1). Pada uji Kruskal Wallis tampak tidak terdapat perbedaan yang bermakna frekuensi defekasi hari pertama, bulan pertama dan bulan kedua pada ketiga kelompok (Tabel 3). Pengamatan pada masing-masing kelompok usia 0 sampai dengan 4 bulan juga menunjukkan adanya penurunan jumlah frekuensi defekasi seiring dengan pertambahan umur bayi. Pada uji Friedman, hanya kelompok ASI eksklusif yang memiliki penurunan yang bemakna pada jumlah frekuensi defekasi bulan I-IV $(p=0,00)$ tertera pada Tabel 4.

Tabel 3. Perbedaan rerata frekuensi defekasi usia 0-4 bulan

\begin{tabular}{lccccccc}
\hline \multirow{2}{*}{$\begin{array}{l}\text { Frekuensi } \\
\text { defekasi }\end{array}$} & \multicolumn{2}{c}{ ASI eksklusif } & \multicolumn{2}{c}{ ASI nonekslusif } & \multicolumn{2}{c}{ Susu formula } & \multirow{2}{*}{ p $^{*}$} \\
\cline { 2 - 6 } & Rerata & SB & Rerata & SB & Rerata & SB & \\
\hline Hari I & 2,81 & $+1,94$ & 2,34 & $+1,56$ & 2,83 & $+1,13$ & 0,293 \\
Hari III & 4,23 & $+2,55$ & 3,04 & $+1,82$ & 2,67 & $+1,17$ & 0,05 \\
Hari VII & 5,81 & $+2,69$ & 3,04 & $+2,01$ & 2,75 & $+1,15$ & 0,00 \\
Bulan I & 3,30 & $+2,49$ & 2,36 & $+1,50$ & 2,03 & $+1,04$ & 0,30 \\
Bulan II & 1,51 & $+1,39$ & 1,81 & $+1,34$ & 1,72 & $+0,78$ & 0,19 \\
Bulan III & 1,08 & $+1,34$ & 1,75 & $+1,14$ & 1,70 & $+0,77$ & 0.01 \\
Bulan IV & 1,00 & $+1,02$ & 1,55 & $+1,01$ & 1,67 & $+0,82$ & 0,01 \\
\hline
\end{tabular}

*Kruskal Wallis

Tabel 4. Perbedaan frekuensi defekasi bulan I sampai IV pada ketiga kelompok

\begin{tabular}{|c|c|c|c|c|c|c|c|c|c|}
\hline \multirow{2}{*}{ Frekuensi defekasi } & \multicolumn{2}{|c|}{ Bulan I } & \multicolumn{2}{|c|}{ Bulan II } & \multicolumn{2}{|c|}{ Bulan III } & \multicolumn{2}{|c|}{ Bulan IV } & \multirow{2}{*}{$\mathrm{p}^{*}$} \\
\hline & Rerata & SB & Rerata & Rerata & SB & SB & Rerata & SB & \\
\hline ASI eksklusif & 3,30 & 2,48 & 1,51 & 1,39 & 1.08 & 1,34 & 1,00 & 1,02 & 0,00 \\
\hline ASI non eksklusif & 2,35 & 1,50 & 1,81 & 1,34 & 1,75 & 1,14 & 1,55 & 1,01 & 0,16 \\
\hline Susu formula & 2,03 & 1,04 & 1,72 & 0,78 & 1,70 & 0,77 & 1,67 & 0,82 & 0,16 \\
\hline
\end{tabular}

* Friedman 


\section{Konsistensi tinja}

Konsistensi tinja kelompok ASI eksklusif mayoritas lembek cair, kecuali pada hari pertama dan tak pernah ada konsistensi yang keras (Gambar 2). Konsistensi tinja lembek mencolok terjadi pada kelompok ASI non-eksklusif dan susu formula (Gambar 3 dan 4).
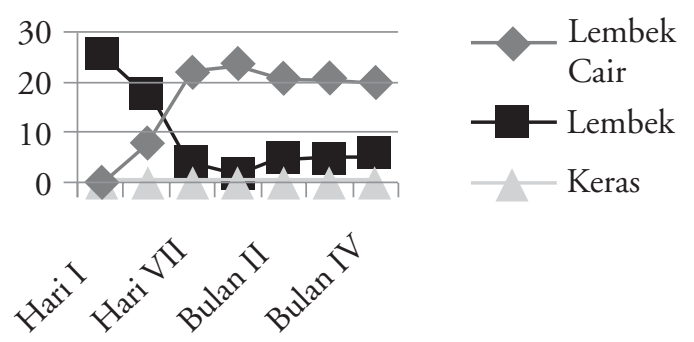

Gambar 2. Konsistensi Tinja kelompok ASI Eksklusif

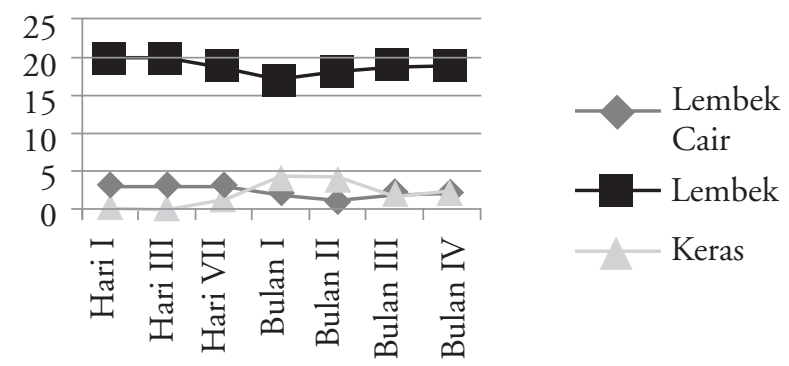

Gambar 3. Konsistensi Tinja kelompok ASI Non Eksklusif

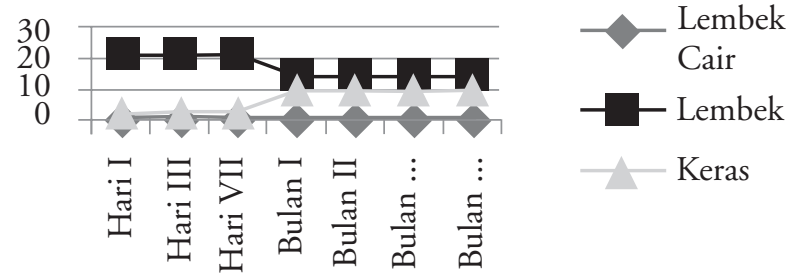

Gambar 4. Konsistensi Tinja kelompok Susu Formula

Tabel 5. Perbedaan konsistensi tinja pada hari pertama, ketiga, dan ketujuh serta bulan pertama. kedua, ketiga, dan keempat

\begin{tabular}{|c|c|c|c|c|c|c|c|}
\hline \multirow{2}{*}{ Konsistensi tinja } & \multicolumn{2}{|c|}{ ASI ekslusif } & \multicolumn{2}{|c|}{ ASI non ekslusif } & \multicolumn{2}{|c|}{ Susu formula } & \multirow{2}{*}{$\mathrm{P}^{*}$} \\
\hline & $\mathrm{n}$ & $\%$ & $\mathrm{n}$ & $\%$ & $\mathrm{n}$ & $\%$ & \\
\hline \multicolumn{8}{|l|}{ Hari pertama } \\
\hline Lembek cair & 0 & 0 & 3 & 13 & 0 & 0 & \multirow{3}{*}{0,028} \\
\hline Lembek & 26 & 100 & 20 & 87 & 22 & 91,7 & \\
\hline Keras & 0 & 0 & 0 & 0 & 2 & 8,3 & \\
\hline \multicolumn{8}{|l|}{ Hari ketiga } \\
\hline Lembek cair & 8 & 30,8 & 3 & 13 & 0 & 0 & \multirow{3}{*}{0,005} \\
\hline Lembek & 18 & 69,2 & 20 & 87 & 21 & 87,5 & \\
\hline Keras & 0 & 0 & 0 & 0 & 3 & 12,5 & \\
\hline \multicolumn{8}{|l|}{ Hari ketujuh } \\
\hline Lembek cair & 22 & 84,6 & 3 & 13 & 1 & 4,2 & \multirow{3}{*}{0,000} \\
\hline Lembek & 4 & 15,4 & 19 & 82,6 & 21 & 87,5 & \\
\hline Keras & 0 & 0 & 1 & 4,3 & 2 & 8,3 & \\
\hline \multicolumn{8}{|l|}{ Bulan pertama } \\
\hline Lembek cair & 24 & 92,3 & 2 & 8,7 & 0 & 0 & \multirow{3}{*}{0,00} \\
\hline lembek & 2 & 7,7 & 17 & 73,9 & 14 & 58,3 & \\
\hline Keras & 0 & 0 & 4 & 17,4 & 10 & 41,7 & \\
\hline \multicolumn{8}{|l|}{ Bulan kedua } \\
\hline Lembek cair & 21 & 80,8 & 1 & 4,3 & 0 & 0 & \multirow{3}{*}{0,00} \\
\hline Lembek & 5 & 19,2 & 18 & 78,3 & 15 & 62,5 & \\
\hline Keras & 0 & 0 & 4 & 17,4 & 9 & 37,5 & \\
\hline \multicolumn{8}{|l|}{ Bulan ketiga } \\
\hline Lembek cair & 21 & 80,8 & 2 & 8,7 & 0 & 0 & \multirow{3}{*}{0,00} \\
\hline Lembek & 5 & 19,2 & 19 & 82,6 & 15 & 62,5 & \\
\hline Keras & 0 & 0 & 2 & 8,7 & 9 & 37,5 & \\
\hline \multicolumn{8}{|l|}{ Bulan keempat } \\
\hline Lembek cair & 20 & 76,9 & 2 & 8,7 & 0 & 0 & \multirow{3}{*}{0,00} \\
\hline Lembek & 6 & 23,1 & 19 & 82,6 & 15 & 62,5 & \\
\hline Keras & 0 & 0 & 2 & 8,7 & 9 & 37,5 & \\
\hline
\end{tabular}

*Pearson Chi square 
Noverita Rochsitasari dkk: Perbedaan frekuensi defekasi dan konsistensi tinja bayi sehat yang mendapat asi eksklusif, non eksklusif, dan susu formula

Tabel 6. Rerata frekuensi defekasi pada berbagai macam konsistensi tinja.

\begin{tabular}{lccccccc}
\hline & \multicolumn{7}{c}{ Frekuensi defekasi (rerata, SB) } \\
\cline { 2 - 8 } Konsistensi tinja & $\begin{array}{c}\text { Hari } \\
\text { pertama }\end{array}$ & $\begin{array}{c}\text { Hari } \\
\text { ketiga }\end{array}$ & $\begin{array}{c}\text { Hari } \\
\text { ketujuh }\end{array}$ & $\begin{array}{c}\text { Bulan } \\
\text { I }\end{array}$ & $\begin{array}{c}\text { Bulan } \\
\text { II }\end{array}$ & $\begin{array}{c}\text { Bulan } \\
\text { III }\end{array}$ & $\begin{array}{c}\text { Bulan } \\
\text { IV }\end{array}$ \\
\hline Lembek cair & $3,67(1,15)$ & $4,64(2,77)$ & $5,42(2,61)$ & $3,48(2,43)$ & $1,54(1,48)$ & $1,16(1,40)$ & $1,09(1,09)$ \\
lembek & $2,63(1,61)$ & $3,17(1,84)$ & $3,23(2,01)$ & $2,22(1,37)$ & $1,91(1,13)$ & $1,71(1,07)$ & $1,57(1,00)$ \\
keras & $2,50(0,70)$ & $2,00(1,00)$ & $1,33(0,58)$ & $1,77(0,76)$ & $1,22(0,66)$ & $1,44(0,59)$ & $1,39(0,99)$ \\
$P^{*}$ & 0,405 & 0,041 & 0,000 & 0,059 & 0,068 & 0,013 & 0,049 \\
\hline
\end{tabular}

*Diuji dengan Kruskal Wallis

Kelompok susu formula tidak pernah memiliki konsistensi tinja yang lembek cair. Konsistensi tinja yang keras didapatkan lebih banyak dibandingkan kelompok susu formula. Berdasarkan hari dan bulan pengamatan, perbedaan konsistensi tinja masingmasing kelompok tertera pada Tabel 5. Perbandingan konsistensi tinja antar kelompok pada hari pertama sampai dengan bulan keempat. Pada uji Pearson Chi Square terdapat perbedaan yang bermakna pada konsistensi tinja antar ketiga kelompok. Untuk mengetahui hubungan frekuensi defekasi bayi pada masing-masing konsitensi tinja dari hari pertama sampai 4 bulan pengamatan tertera pada Tabel 6 .

Pengamatan hari pertama, bulan pertama, dan kedua menunjukkan bahwa makin keras konsistensi tinja maka makin rendah rerata frekuensi defekasinya, namun setelah diuji dengan Kruskal Wallis tidak menunjukkan perbedaan yang bermakna. Pengamatan hari ketiga, ketujuh, bulan ketiga dan keempat terdapat perbedaan yang bermakna frekuensi defekasi pada masing-masing konsistensi tinja secara berturut turut ditunjukkan dengan $\mathrm{p}=0,041$ pada hari ketiga, $\mathrm{p}=0,000$ pada hari ketujuh, $\mathrm{p}=0,013$ pada bulan ketiga dan $\mathrm{p}=0,049$ pada bulan keempat.

\section{Pembahasan}

Sesuai dengan penelitian oleh Tunc, Weafer, Corazziari dan Myo-Khin ${ }^{6-9}$ yang menemukan frekuensi defekasi akan berkurang seiring dengan bertambahnya umur bayi. Frekuensi defekasi paling tinggi pada bulan pertama (median=6), kemudian berkurang berkurang seiring dengan bertambahnya umur bayi $(\mathrm{p}=0001) .^{7}$ Penelitian pada bayi sehat di Thailand oleh Benjasuwantep ${ }^{10}$ juga menunjukkan frekuensi defekasi selama masa neonatus sangat bervariasi, dengan rentang satu sampai dengan sepuluh kali perhari. Rerata frekuensi defekasi paling tinggi juga terdapat pada masa neonatus $(3,16$ kali perhari) kemudian berkurang secara bermakna seiring dengan peningkatan usia.

Penelitian kami menunjukkan rerata frekuensi defekasi tertinggi pada usia satu minggu pertama kemudian berkurang pada umur selanjutnya pada semua kelompok jenis makanan. Pada bayi baru lahir umumnya mempunyai aktivitas laktase belum optimal sehingga kemampuan menghidrolisis laktosa yang terkandung di dalam ASI maupun susu formula juga terbatas. Keadaan tersebut menyebabkan peningkatan tekanan osmolaritas di dalam lumen usus halus yang mengakibatkan peningkatan frekuensi defekasi. ${ }^{21,22}$ Selain itu waktu transit intestinal meningkat seiring dengan bertambah umur bayi. ${ }^{2}$ Rentang frekuensi defekasi pada minggu pertama sangat bervariasi, minimal 1 kali per hari. Rentang terluas terdapat pada kelompok ASI yaitu 1-12 kali per hari. Sesuai dengan penelitian Tehuteru ${ }^{2}$ yang meneliti pola defekasi bayi ASI eksklusif 0-4 bulan, menyebutkan bayi yang mendapatkan ASI eksklusif memiliki frekuensi defekasi paling tinggi pada minggu pertama. Hal tersebut disebabkan karena kolostrum ASI yang merupakan laksatif alami keluar pada satu minggu pertama setelah bayi lahir.

Pada pengamatan bulan pertama frekuensi defekasi kelompok susu formula memiliki frekuensi defekasi yang paling rendah. Selain kolostrum yang tidak terdapat dalam susu formula, fungsi enzim bayi yang belum sempurna juga dapat menyebabkan frekuensi defekasi yang sering. Selain itu ASI kaya dengan protein dan oligosakarida yang tak dapat dicerna, sehingga dapat meningkatkan volume, osmolaritas dan akhirnya dapat meningkatkan frekuensi defekasi. Frekuensi menetek yang sering 
akan menyebabkan stimulasi pada reflek gastrokolik dan frekuensi defekasi yang lebih sering. ${ }^{2}$ Kandungan prostaglandin dalam ASI juga memiliki peran terhadap motilitas gastrointestinal yang membantu terjadinya peristaltik. ${ }^{6}$ Frekuensi defekasi yang sering tersebut tidak memenuhi kriteria diare, karena bayi tidak mengalami kehilangan cairan (dehidrasi) dan elektrolit dari saluran cerna. ${ }^{20}$

Hasil pengamatan pada bulan ketiga bayi pada kelompok ASI eksklusif memiliki frekuensi defekasi paling jarang dibandingkan engan kelompok yang lain. Frekuensi yang jarang tersebut oleh karena ASI dapat diabsorbsi sampai $100 \% .{ }^{10}$ Walaupun jarang, namun tidak memenuhi kriteria konstipasi, ${ }^{21}$ maka tidak dianggap sebagai hal yang patologis. Proporsi whey yang lebih tinggi pada ASI lebih mudah diserap dibandingkan dengan susu sapi yang mengandung proporsi kasein yang lebih tinggi. ${ }^{22,23}$ Hasil penelitian kami menunjukkan perbedaan konsistensi tinja pada ketiga kelompok. Kelompok ASI ekslusif cenderung memiliki konsistensi tinja lembek cair dibandingkan dengan kelompok ASI non ekslusif dan susu formula. Konsistensi tinja yang keras lebih banyak ditemukan pada kelompok susu formula. Tunc ${ }^{5}$ mengemukakan terdapat perbedaan konsistensi tinja yang bermakna pada bayi yang mendapat ASI eksklusif bila dibandingkan dengan bayi yang mendapatkan ASI dan susu formula pada umur 0-4 bulan. Sebaliknya pada penelitian yang dilakukan Bekali, tidak ditemukan perbedaan yang bermakna pada konsistensi tinja pada bayi yang mendapatkan ASI dan susu formula $(\mathrm{p}=0,07) .{ }^{12}$ Penelitian sebelumnya juga menunjukkan bahwa kepadatan tinja bayi yang mendapatkan ASI eksklusif lebih rendah dibandingkan dengan bayi yang mendapat susu formula. ${ }^{11}$ Bayi normal lebih mudah mencerna dan menyerap lemak yang berasal dari ASI dibandingkan lemak susu sapi atau susu formula, disebabkan ASI mengandung lipase, juga mengandung amilase dan protease. ${ }^{15,16}$

Asam palmitat pada ASI 70\% berada di posisi Sn2. Pada posisi tersebut palmitat tidak dihidrolisis oleh lipase pankreas, dan 2-monoacyglyserol yang dihasilkan membentuk emulsi yang disebut micelles dan micelles ini mudah diserap. Sebaliknya pada susu formula atau susu sapi, asam palmitat menempati posisi $S n 1$ dan $\mathrm{Sn} 3$, sehingga asam palmitat membutuhkan hidrolisis oleh lipase pankreas. Proses hidrolisis tersebut menghasilkan asam palmitat bebas, yang akan bereaksi dengan kalsium sehingga membentuk calcium fatty acid soaps yang sulit diserap. ${ }^{10,24}$ Oleh karena itu tinja bayi yang mendapatkan susu fomula lebih banyak mengandung mineral dan lemak, dan karbohidrat lebih rendah. Pembentukan calcium fatty acid soaps berhubungan secara bermakna dengan tingkat kepadatan, sehingga tinja dengan kandungan asam palmitat $\mathrm{Sn} 2$ yang rendah akan lebih padat dibandingkan dengan tinja yang mengandung palmitat Sn2 yang tinggi. ${ }^{11,21,25}$ Lawrence ${ }^{5}$ menyampaikan penurunan frekuensi defekasi juga dihubungkan dengan peningkatan waktu singgah makanan di dalam saluran cerna (waktu transit intestinal), sehingga semakin jarang frekuensi defekasi, maka konsistensi tinja akan semakin padat.

Pada hari pertama tidak menunjukkan perbedaan oleh karena sebagian besar bayi mengeluarkan tinja mekoneum dengan konsistensi lembek dan pekat. Frekuensi yang sering pada konsistensi lembek cair disebabkan, sebagian besar bayi yang memiliki konsistensi lembek cair adalah bayi yang mendapatkan ASI ekslusif. Telah disebutkan peran kolostrum dalam ASI yang bersifat laksatif sangat penting terhadap frekuensi defekasi pada hari-hari pertama kehidupan.

Pengamatan pada hari ketiga tidak terdapat perbedaan frekuensi pada ketiga kelompok. Hal tersebut berhubungan dengan jumlah cairan yang dikonsumsi bayi, karena volume ASI yang keluar dari ibu belum mencukupi. Penelitian kami tidak dapat mengukur volume ASI ibu tiap kali anak minum. Namun bila dilihat kembali bahwa proporsi rerata frekuensi defekasi tetap lebih tinggi pada bayi dengan tinja lembek cair dibandingkan dengan kelompok lain.

Pengamatan pada bulan pertama dan kedua tidak terdapat perbedaan frekuensi defekasi yang bermakna pada ketiga kelompok. Pada bulan pengamatan tersebut frekuensi defekasi bayi dengan kelompok ASI eksklusif mulai jarang, tidak setiap hari bayi mengalami defekasi, bahkan dapat mencapai 7 sampai 10 hari sekali. Frekuensi bayi pada kelompok ASI non-eksklusif dan susu formula lebih teratur, terutama pada kelompok susu formula bayi dapat setiap hari defekasi. Selain itu bayi kelompok ASI eksklusif tidak pernah memiliki tinja yang keras, dan kelompok susu formula tidak pernah memiliki konsistensi tinja yang lembek cair.

Pengamatan pada bulan ketiga dan keempat didapatkan perbedaan frekuensi defekasi menurut 
konsistensi tinja. Frekuensi defeksi pada tinja dengan konsistensi lembek paling tinggi dibandingkan dengan konsistensi tinja lembek cair dan keras. Temuan tersebut tidak sesuai dengan kepustakaan sebelumnya yang menyebutkan semakin keras konsistensi tinja, maka makin jarang frekuensi defekasinya. Frekuensi defekasi bayi yang mendapat ASI eksklusif paling jarang, namun tidak satupun dari mereka memiliki konsistensi tinja keras.

\section{Kesimpulan}

Rerata frekuensi defekasi bayi kelompok ASI eksklusif pada bulan pertama lebih tinggi dibandingkan kelompok lain, namun setelah bulan pertama menjadi lebih jarang dibandingkan dengan kelompok lain. Terdapat perbedaan frekuensi defekasi pada ketiga kelompok bayi sehat pada hari ketiga, ketujuh, bulan ketiga dan keempat pengamatan. Terdapat perbedaan konsistensi tinja pada ketiga kelompok bayi selama masa pengamatan, dan hubungan frekuensi defekasi dengan konsistensi tinja pada pengamatan hari ketiga, ketujuh, bulan ketiga, dan keempat.

\section{Daftar pustaka}

1. The digestive diseases dictionary. Diunduh dari URL : http://medicine.iupiu.edu/heartburn/dictionary/a-z.htm diakses pada tanggal 2 Oktober 2008.

2. Tehuteru ES, Hegar B, Firmansyah A. Pola defekasi pada anak. Sari Pediatri 2001;3: 129 - 33.

3. Murphy MS, Clayden G. Constipation. Dalam: Walker WA, Durie PR, Hamilton JR, Walker-smith JA, Watskin JB, penyunting. Pediatric gastrointestinal disease. Edisi kedua. USA : Mosby; 1996.h. 293321.

4. Bekkali N, Hamers SL, Rbtsma JB, Toledo LV, Benninga MA. Infant stool form scale: development and results. J Pediatr 2009; 154:521-6.

5. Lawrence RA. Breastfeeding, a guide for the medical profession. Edisi ke-4. Missouri: Mosby; 1994.h.91215.

6. Tunc VT, Camurdan A D, lhan M N, Sahin F, Beyazova U. Factors Associated with Defecation Patterns in 0-24month-old Children. Eur J Pediatr 2008.

7. Weaver LT, Ewing G, Taylor LC The bowel habit of milkfed infants. J Pediatr Gastroenterol Nutr 1988; 7:568-71.
8. Corazziari E, Staiano A, Miele E, Greco L Bowel frequency and defecatory patterns in children: a prospective nationwide survey. Clin Gastroenterol Hepatol 2005;3:1101-6.

9. Myo-Khin, Thein-Win-Nyunt, Kyaw-Hla S, TheinThein-Myint, Bolin TD. A prospective study on defecation frequency, stool weight, and consistency. Arch Dis Child.1994;71:311-3.

10. Benjasuwantep B, Ruangdaraganon N. Bowel movements of normal Thai infants. Southeast As J Trop Med Pub Health 2009; 40:530-7.

11. Al-Ayed IH. Mothers' knowledge of child health matters: Are we doing enough?. J Fam Community Med 2010;17:22-8.

12. Tuheteru ES, Firmansyah A, Madiyono B. Bowel habits of exclusively breasfed 0-4 month-old babies. Pediatr Indones 2004;44:138-42.

13. Forbes D, Kendall G, Zubrick S, Stanley F. patterns of defecation in childhood: a population study in Western Australian children. J Pediatr Gastroenterol Nutr 2005; Suppl 1: 41 .

14. Metaj M, Laroia N, Lawrence RA, Ryan RM. Comparison of breast- and formula-fed normal newborns in time to first stool and urine. J Perinatol 2003; 23:624-8.

15. Neu J, Nan Li. The neonatal gastrointestinal tract: developmental anatomy, physiology and clinical implications. Neo Reviews.2003;4 :e7-13.

16. Lebenthal E, Kretchmer N, Alliet P.Laktase deficiency, lactose malabsorbtion, and lactose intolerance. Dalam: Lebenthal E, penyunting. Texbook of gastrointestinal and nutrition in infancy. New York: Raven Press 1989.h.45972.

17. Newell SJ. Gastrointestinal disorder. Dalam : Rennie Jm, penyunting. Roberton's textbook of neonatology. Edisi ke-4. London: Elsevier; 2005.h.692-710.

18. Vanderhoff JA,Zach TL,Adrian TE. Gastrointestinal disease. Dalam: MacDonald MG, Seshia MM, Mullet MD, penyunting. Avery's neonatology: pathophysiology \& management of the newborn. Edisi ke-6. Philadelphia: Lippincott Williams \& Wilkins;2005.h.940-64.

19. Lo'pez-Lo'pez A, Castellote-Bargallo' AI, CampoyFolgoso C, Rivero-Urgel M, Tormo-Carnice' R, Infante-Pina $\mathrm{D}, \mathrm{dkk}$. The influence of dietary palmitic acid triacylglyceride position on the fatty acid, calcium and magnesium contents of at term newborn faeces. Early Human Development 2001; Suppl 65: S83S94. 
20. Veereman-Wauters, Taminiau J. Diarrhea. Dalam: Pediatric gastrointestinal and liver disease, pathophysiology, diagnosis, management. Edisi ketiga. Philadelphia: Elsevier, Inc; 2006. h.151-7.

21. Cunningham CL, Banez GA. Pediatric gastrointestinal disorders: Biopsychosocial assessment and treatment. USA: S pringer; 2006.h.127-160.

22. Uauy R, Mena P,. Warshaw JB. Growth and metabolic adaptation of the fetus and newborn. Dalam : McMillan JA, Deangelis CD, FeiginRD, Warshaw JB, Oski FA, penyunting. Oski's pediatrics: principles and practice,
Edisi ke-3. Philadelphia: Lippincott Williams \& Wilkins;1999.h. 376.

23. Biancuzzo. Breasteeding the Newborn:clinical strategies for nurses. Edisi ke-2. USA: Mosby;2003.h.53-75.

24. Djais JT. Functional food: Perannya pada saluran cerna. Dalam: Kumpulan makalah kongres nasional II badan koordinasi gastroenterology anak Indonesia (BKGAI). Bandung: IDAI; 2003.h.319-26.

25. Lloyd B, halter RJ, Kuchan MJ, Baggs GE, Ryan AS, Masor ML. Formula tolerance in postbreastfed and exsklusively formula-fed infants. Pediatric 1999;103:e7. 